\title{
Pengaruh Pengawasan, Motivasi dan Disiplin Terhadap Kinerja Guru pada Yayasan Pendidikan Islam Terpadu Kuntum Bumi Rantauprapat
}

\author{
Sutan Napsan Nasution \\ Sjahril Effendy Pasaribu
}

Program Studi Magister Manajemen, Universitas Muhammadiyah Sumatera Utara Medan, Indonesia Jl. Denai No. 217, Tegal Sari Mandala II, Medan Denai, Kota Medan, Sumatera Utara 20371

Email : sult6619@gmail.com

\begin{abstract}
Abstrak. Penelitian ini dilatarbelakangi oleh sumber daya manusia merupakan salah satu faktor yang sangat penting dan tidak bisa dilepaskan dari sebuah organisasi, baik perusahaan ataupun instuisi.Pada dasarnya terdapat berbagai faktor yang mempengaruhi keberhasilanpendidikan antara lain adalah guru, siswa, lingkungan pendidikan, manajemen sekolah, dan kurikulum. Dari beberapa faktor tersebut, guru merupakan faktor penting yang tidak dapat dipisahkan pada sistem pembelajaran.Tujuan penelitian ini yaitu ingin mengetahui dan menganalisis pengaruh pengawasan, motivasi dan disiplin terhadap kinerja guru pada YPIT Kuntum Bumi Rantauprapat. Penelitian ini menggunakan pendekatan asosiatif, pendekatan asosiatif adalah pendekatan dimana untuk mengetahui bahwa adanya hubungan atau pengaruh diantara kedua variabel (variabel bebas dan variabel terikat). Hasil penelitian menunjukkan bahwa secara parsial pengawasan, motivasi dan disiplin kerja dan berpengaruh positif tidak signifikan terhadap kinerja guru pada Yayasan Pendidikan Islam Terpadu Kuntum Bumi Rantauprapat. Dan secara simultan pengawasan, motivasi dan disiplin kerja secara simultan berpengaruh positif signifikan terhadap kinerja guru pada Yayasan Pendidikan Islam Terpadu Kuntum Bumi Rantauprapat.
\end{abstract}

Kata Kunci : Pengawasan, Motivasi, Disiplin, Kinerja Guru

\begin{abstract}
This research is motivated by human resources is one of the most important factors and cannot be separated from an organization, either a company or an institution. Basically there are various factors that influence the success of education including teachers, students, educational environment, school management, and curriculum . From these factors, the teacher is an important factor that cannot be separated in the learning system. The purpose of this study is to find out and analyze the influence of supervision, motivation and discipline on teacher performance on YPIT Kuntum Bumi Rantauprapat. This study uses an associative approach, an associative approach is an approach in which to find out that there is a relationship or influence between the two variables (the independent variable and the dependent variable). The results showed that partial supervision, motivation and work discipline and not a significant positive effect on teacher performance at the Kuntum Bumi Rantauprapat Integrated Islamic Education Foundation. And simultaneous supervision, motivation and work discipline simultaneously have a significant positive effect on teacher performance at the YPIT Kuntum Bumi Rantauprapat
\end{abstract}

Keywords : Supervision, Motivation, Discipline, Teacher Performance

\section{PENDAHULUAN}

Setiap organisasi selalu berkeinginan agar tujuannya dapat tercapai dimana indikator ketercapaiannya adalah ketika apa yang direncanakan dapat terlaksana, baik untuk jangka pendek maupun jangka panjang. Agar apa yang direncanakan dapat terlaksana dengan baik, maka dibutuhkan peran serta secara aktif dari segenap komponen yang ada dalam organisasi karena prestasi organisasi hanya mungkin diraih manakala setiap elemen dalam organisasi berupaya untuk memberikan kontribusi terbaiknya. Untuk mengukur besar kecilnya kontribusi 
yang telah diberikan, maka diperlukan adanya penilaian kinerja dari masing-masing komponen dalam organisasi (Arianty, Bahagia, Lubis, \& Siswadi, 2016).

Kegiatan organisasi tidak akan berjalan tanpa adanya keterlibatan unsur manusia yang ada didalamnya. Unsur pengendalian ada pada manusia, sehingga pada akhirnya dibanding dengan faktor-faktor yang lain, maka manusia merupakan unsur yang paling menentukan keberhasilan atau kegagalan suatu organisasi dalam menyelenggarakan berbagai kegiatan dalam rangka pencapaian tujuan dan berbagai sasaran organisasi. Tercapainya tujuan suatu lembaga atau organisasi tidak hanya tergantung pada peralatan modern, sarana dan prasarana yang lengkap, betapapun sempurnanya aspekteknologi dan ekonomi, tanpa aspek manusia sulit kiranya tujuan-tujuan organisasi dapat dicapai, tergantung pada manusia yang melaksanakan pekerjaan tersebut. Manusia merupakan sumber daya paling penting dalam usaha organisasi mencapai keberhasilan. Faktor penting disini sifatnya kompleks sehingga perlu perhatian, penanganan, dan perlakuan khusus disamping faktor yang lain (Raihana Daulay, Pasaribu, Putri, \& Astuti, 2017).

Pada dasarnya terdapat berbagai faktor yang mempengaruhi keberhasilanpendidikan antara lain adalah guru, siswa, lingkungan pendidikan, manajemen sekolah, dan kurikulum. Dari beberapa faktor tersebut, guru merupakan faktor penting yang tidak dapat dipisahkan pada sistem pembelajaran. Guru merupakan aset penting dan berharga terutama di sekolah. Apabila dikelola dengan baik maka kinerja guru juga akan baik.

Kinerja guru yang diharapkan dapat mendongkrak kualitas dan relevansi pendidikan, dalam implementasinya dilapangan. Guru merupakan salah satu faktor yang sangat dominan dalam menentukan kualitas peserta didiknya. Dalam Undang-Undang Republik Indonesia No. 14 tahun 2005 tentang guru dan dosen pasal 1 disebutkan guru adalah pendidik professional dengan tugas utama mendidik, mengajar, membimbing, mengarahkan, melatih, menilai, dan mengevaluasi peserta didik pada pendidikan anak usia dini jalur pendidikan formal, pendidikan dasar, dan pendidikan menengah.

Guru yang profesional adalah guru yang mengedepankan mutu dan kualitas pendidikan. Layanan guru harus memenuhi standarisasi kebutuhan masyarakat, bangsa, dan pengguna serta memaksimalkan kemampuan peserta didik berdasarkan potensi dan kecakapan yang dimiliki masing-masing individu. Untuk menjadi guru yang professional harus memiliki beberapa kompetensi. Dalam Undang-Undang Guru dan Dosen No. 14 tahun 2005 Bab IV pasal 10 ayat 1 menjelaskan kompetensi yang harus dimiliki seorang guru meliputi kompetensi kepribadian, kompetensi sosial, dan kompetensi profesional. Semua kompetensi tersebut harus dimiliki oleh seorang guru dalam menjalankan tugas dan tanggung jawabnya agar mempunyai kinerja yang baik.

Kinerja yang baik merupakan perwujudan kerja yang dilakukan oleh guru yang biasannya dipakai sebagai dasar penilaian terhadap anggota dan organisasi, sehingga perlu diupayakan untuk meningkatkan kinerja. Peningkatan kinerja guru dapat dilihat dari rasa puas atau senang terhadap pekerjaannya atau profesinya.

Kinerja guru adalah kegiatan guru dalam proses pembelajaran yaitu bagaimana guru merencanakan pembelajaran, melaksanakan kegiatan pembelajaran, dan menilai serta mengevaluasi pembelajarannya. Kinerja guru diharapkan dapat mendongkrak kualitas dan relevansi pendidikan, dalam implementasinya di lapangan tergantung dari banyak faktor yang mempengaruhinya dan saling berkaitan, misalnya faktor pengawasan, faktor motivasi dan faktor kedisiplinan.

Setiap guru belum tentu bersedia mengerahkan produktivitas kerja yang di milikinya secara optimal, sehingga masih di perlukan adanya pendorong agar seseorang mau menggunakan seluruh potensinya untuk bekerja. Daya dorong tersebut lazim di sebut motivasi 
yang salah satunya dilakukan melalui pengawasan terhadap guru dalam bekerja, sehingga pengawasan akan mendorong seseorang melakukan suatu kegiatan dengan menggunakan seluruh kemampuannya untuk mencapai tujuan. Seorang guru akan mengerahkan segenap kemampuannya untuk melaksanakan pekerjaan bilamana dalam mengerjakan pekerjaan tersebut terdapat sistem pengawasan yang terkoordinir dan aturan disiplin yang jelas.

Keberhasilan organisasi tergantung pada kinerja para pelaku organisasi bersangkutan. Oleh karena itu, setiap unit kerja dalam suatu organisasi harus dinilai kinerjanya, agar kinerja sumber daya manusia yang terdapat dalam unit-unit dalam suatu organisasi tersebut dapat dinilai secara objektif. Para bawahan yang selalu mendapat pengarahan atau bimbingan dari atasan, cenderung melakukan kesalahan atau penyimpangan yang lebih sedikit dibandingkan dengan bawahan yang tidak memperoleh bimbingan. Sasaran pengawasan adalah agar tidak terjadi penyimpangan dalam pelaksanaan pekerjaan, atau dengan kata lain bahwa pengawasan adalah fase untuk menilai apakah sasaran-sasaran yang ditetapkan telah dicapai dengan memuaskan atau tidak.

Di samping itu, pekerjaan haruslah dimotivasi secara terus-menerus agar tetap semangat untuk melakukan pekerjaannya. Dalam konteks pekerjaan, motivasi merupakan salah satu faktor penting dalam mendorong seseorang untuk menghasilkan kinerja. Motivasi merupakan serangkaian sikap dan nilai-nilai yang mempengaruhi individu untuk mencapai hal yang spesifik sesuai dengan tujuan individu. Sikap dan nilai tersebut merupakan suatu yang invisible yang memberikan kekuatan untuk mendorong individu untuk bertingkah laku dalam mencapai tujuan. Bila seseorang termotivasi maka ia akan berupaya sekuat tenaga untuk mencapai tujuan, namun belum tentu upaya yang tinggi akan menghasilkan kinerja yang tinggi. Oleh karena itu, diperlukan intensitas dan kualitas dari upaya tersebut serta difokuskan pada tujuan organisasi. Pada umumnya kinerja yang tinggi dihubungkan dengan motivasi yang tinggi. Sebaliknya, motivasi yang rendah dihubungkan dengan kinerja yang rendah. Kinerja yang tinggi adalah fungsi dan interaksi antara motivasi, kompetensi dan peluang sumber daya pendukung.

Selanjutnya, kinerja juga di pengaruhi faktor disiplin. Disiplin kerja adalah sikap kejiwaan atau kelompok yang senantiasa berkehendak untuk mengikuti dan mematuhi segala peraturan yang di tentukan. Disiplin kerja juga harus di perhatikan oleh seluruh anggota organisasi agar tujuan organisasi yang telah ditetapkan sebelumnya dapat tercapai. Penerapan disiplin kerja dalam suatu organisasi akan menjadi pedoman bagi guru, sehingga dapat mewujudkan tujuan organisasi.Salah satu kunci keberhasilan adalah terletak pada kedisiplinan, dan sebuah kedisiplinan yang baik adalah walaupun kecil namun dilakukan secara terus menerus. Karena dengan dilakukan secara terus menerus maka hasil dari kedisiplinan tersebut akan membuahkan hasil nyata yang akan terlihat dimasa yang akan datang.

Berdasarkan hasil riset awal pada Yayasan Pendidikan Islam Terpadu atau disingkat dengan YPIT Kuntum Bumi Rantauprapat terhadap kinerja guru dinilai masih kurang maksimal, hal tersebut ditandai oleh menurunnya hasil kerja yang dicapai dari sebagian guru khususnya dalam melaksanakan pekerjaan yang telah ditentukan oleh yayasan.Selain itu, kurangefektifnya pengawasan yang dilakukan pihak yayasan terhadap kinerja guru. Selain itu, motivasi kerja guru dinilai masih belum maksimal, hal ini terlihat dari sebagian guru yangterkesan kurang termotivasi dalam bekerja dikarenakan kurangnya perhatian atasan terhadap hasil kinerja guru serta disiplin kerja guru masih rendah, dimana masih ada sebagian guru yang kurang mentaati disiplin kerja, hal tersebut terlihat dengan masih adanya guru yang tidak melaksanakan tugas piket kebersihan, dan sebagian guru terkesan mengulur-ulur waktu dalam menyelesaikan pekerjaannya. Hal tersebut disebabkan oleh kurangnya pengawasan yang 
dilakukan oleh pihak yayasan, sehingga para guru terkesan santai dan tenang apabila mereka tidak mengerjakan tugas mereka dengan baik.

\section{KAJIAN LITERATUR \\ Kinerja}

Kinerja merupakan perilaku nyata yang ditampilkan setiap orang sebagai prestasi kerja yang dihasilkan oleh pegawai sesuai perannya dalam instansi. Kinerja merupakan suatu hal yang sangat penting dalam upaya instansi untuk mencapai tujuannya. Menurut (Mangkunegara, 2018), kinerja atau prestasi kerja adalah hasil kerja secara kualitas dan kuantitas yang di capai oleh seorang pegawai dalam melaksanakan tugasnya sesuai dengan tanggung jawab yang di berikan kepadanya.

Kemudian (Kasmir, 2016) menjelaskan bahwa kinerja merupakan hasil kerja dan perilaku kerja seseorang dalam suatu periode, biasanya 1 tahun. Kinerja adalah bagaimana sesorang yang diharapkan dapat berfungsi dan berperilaku sesuai dengan tugas yang telah dibebankan kepadanya (Miner dalam Sutrisno, 2016)

Sedangkan menurut Atmoseoprapto dalam (Agustini, 2011) menjelaskan bahwa kinerja adalah perbandingan antara keluaran (output) yang di capai dengan masukan (input) yang diberikan. Selain itu, kinerja juga merupakan hasil dari efesiensi pengelolaan masukan dan efektivitas pencapaian sasaran.

Dari beberapa pengertian diatas maka dapat disimpulkan bahwa kinerja atau prestasi kerja merupakan hasil kerja yang dapat dicapai pegawai dalam suatu organisasi, sesuai dengan wewenang dan tanggung jawab yang di berikan organisasi dalam upaya mencapi visi, misi dan tujuan organisasi bersangkutan secara legal, tidak melanggar hukum dan sesuai dengan moral maupun etika. Adapun faktor-faktor yang mempengaruhi kinerja menurut (Sutrisno, 2016) yaitu efektifitas dan efisiensi, otoritas dan tanggung jawab, disiplin kerja dan inisiatif. Faktor-faktor lain yang mempengaruhi pencapaian kerjamenurut (Mangkunegara, 2018) adalah faktor kemampuan dan faktor motivasi.

Untuk mengukur kinerja dapat di gunakan beberapa indikator mengenai kriteria kinerja yakni: kualitas, kuantitas, ketepatan waktu, efektivitas biaya, kebutuhan akan pengawasan, dan hubungan antar perseorangan. Indikator inilah yang akan menjadi patokan dalam mengukur kinerja, (Kasmir, 2016) yaitu kualitas (mutu), kuantitas (jumlah), waktu (jangka waktu), penekanan biaya, pengawasan dan hubungan antar rekan kerja. Sedangkan indikator lain dari kinerja menurut (Mangkunegara, 2018) adalah kualitas kerja, kuantitas kerja, keandalan dan sikap.

\section{Pengawasan}

Pengawasan adalah proses pengamatan daripada pelaksanaan seluruh kegiatan organisasi untuk menjamin agar supaya semua pekerjaan yang sedang dilakukan berjalan sesuai dengan rencana yang telah ditentukan sebelumnya (Raihanah Daulay, Khair, Pratami, \& Astuti, 2017). Pengawasan merupakan fungsi manajemen yang sangat berkaitan erat dengan pencapaian tujuan organisasi atau perusahaan, sehingga pengawasan dalam organisasi apapun menjadi mutlak dilakukan. Winardi, (2012) menyatakan pengawasan adalah suatu upaya yang sistematik untuk menetapkan kinerja standar pada perencanaan untuk merancang sistem umpan balik informasi, untuk membandingkan kinerja actual dengan standar yang telah ditentukan. Handoko, (2010) menyatakan bahwa pengawasan adalah suatu proses untuk menjamin bahwa tujuan-tujuan organisasi dan manajemen tercapai, ini berkenaan dengan cara-cara membuat kegiatan-kegiatan sesuai dengan yang direncanakan. Kadarisman, (2014) menyatakan pengawasan adalah merupakan fungsi di dalam manajemen fungsional yang harus 
dilaksanakan oleh setiap pimpinan semua unit/satuan kerja terhadap pelaksanaan pekerjaan dilingkunganya. Terdapat beberapa faktor yang menjadi pertimbangan dalam menerapakan pengawasan kepada setiap pegawai atau karyawan di suatu perusahaan atau Instansi pemerintah.

Pengawasan yang efektif membantu usaha dalam mengatur pekerjaaan agar dapat terlaksana dengan baik. Fungsi pengawasan merupakan fungsi terakhir dari proses manajemen. Fungsi ini terdiri dari tugas-tugas memonitor dan mengevaluasi aktivitas organisasi agar target organisasi tercapai. Dengan kata lain fungsi pengawasan menilai apakah rencana yang ditetapkan pada fungsi perencanaan telah tercapai. Pengawasan mencakup upaya memeriksa apakah semua terjadi sesuai dengan rencana yang ditetapkan, perintah yang dikeluarkan, dan prinsip yang dianut. Juga dimaksudkan untuk mengetahui kelemahan dan kesalahan agar dapat dihindari kejadiannya dikemudian hari.

Menurut (Handoko, 2010) terdapat berbagai faktor yang membuat pengawasan semakin di perlukan oleh setiap organisasi. Faktor-faktor tersebut adalah perubahan lingkungan organisasi, peningkatan kompleksitas organisasi, kesalahan-kesalahan dan kebutuhan atasan untuk mendelegasikan wewenang. Umam, (2012) menyebutkan faktor-faktor yang mempengaruhi pengawasan yaitu: perubahan lingkungan, peningkatan kolektifitas organisasi, kesalahan-kesalahan dan kebutuhan manajer untuk mendelegasikan wewenang.

Untuk mengawasi pelaksanaan kegiatan agar lebih efektif maka setiap organisasi haruslah merencanakan dan menyusun suatu sistem pengawasan. Sistem pengawasan yang disusun oleh suatu organisasi belum tentu sama dengan organisasi lainnya, perbedaan tersebut dapat saja disebabkan oleh beberapa faktor, antara lain besarnya perubahan dan jenis kegiatannya. Oleh karena itu pengawasan harus dilakukan dengan baik dan efisien agar dapat menangani berbagai penyimpangan-penyimpangan yang terjadi. Adapun indikator pengawasan menurut (Handoko, 2010) adalah akurat, tepat waktu, objektif dan menyeluruh, terpusat pada titik pengawasan strategik, realistis secara ekonomis, realistis secara organisasional, terkoordinasi dengan aliran kerja organisasi, fleksibel, bersifat sebagai petunjuk dan operasional dan dapat diterima para organisasi.

\section{Motivasi}

Motivasi merupakan kegiatan yang mengakibatkan seseorang menyelesaikan pekerjaannya dengan semangat, rela dan penuh tanggung jawab. Motivasi berfungsi sebagai penggerak atau dorongan kepada para pegawai agar mau bekerja dengan giat demi tercapainya tujuan instansi secara baik, untuk lebih jelasnya berikut ini pengertian motivasi menurut para ahli. Menurut (M. S. . Hasibuan, 2014) motivasi adalah pemberian daya penggerak yang menciptakan kegairahan kerja seseorang, agar mereka mau bekerja sama, bekerja efektif, dan terintegrasi dengan segala daya upayanya untuk mencapai kepuasan.

Sedangkan menurut (Siagian, 2014) motivasi kerja adalah daya pendorong yang mengakibatkan seseorang anggota organisasi mau dan rela untuk mengarahkan kemampuan dalam bentuk keahlian dan keterampilan tenaga dan waktunya untuk menyelenggarakan berbagai kegiatan yang menjadi tanggung jawabnya dan menunaikan kewajibannya, dalam rangka pencapaian tujuan dan berbagai sasaran yang telah ditentukan oleh instansi sebelumnya.

Hal ini sesuai dengan yang di uraikan Abraham dalam (Mangkunegara, 2018) motivasi adalah suatu kecendrungan untuk beraktifitas, dimulai dari dorongan dalam diri (drive) dan diakhiri dengan penyesuaian diri. Penyesuaian diri dikatakan untuk memuaskan motivasi.

Motivasi merupakan dorongan untuk bertindak terhadap serangkaian proses perilaku manusia dengan mempertimbangkan arah, intensitas, dan ketekunan pada pencapaian tujuan. 
Adapun elemen yang terkandung dalam motivasi meliputi unsur membangkitkan, mengarahkan, menjaga, bersifat terus-menerus dan adanya tujuan (Wibowo, 2014).

Berdasarkan definisi yang telah dikemukakan dari para ahli maka dapat disimpulkan bahwa dalam pemberian motivasi tidak terlepas dari kemampuan seorang pemimpin untuk dapat mempengaruhi, memotivasi, mengarahkan serta berkomunikasi dengan para pegawai. Hal ini berkaitan dengan bagaimana cara pemimpin dapat memotivasi pegawainya dalam hal pelaksanaan kegiatan dan meningkatkan kinerja sesuai yang diinginkan. Menurut (Sunyoto, 2012) faktor-faktor yang mempengaruhi motivasi ada yaitu: promosi, prestasi kerja, pekerjaan itu sendiri, penghargaan, tanggung jawab, pengakuan dan keberhasilan dalam bekerja. Motivasi adalah suatu faktor yang mendorong seseorang untuk melakukan suatu aktifitas tertentu. Adapun indikator motivasi kerja menurut (Mangkunegara, 2018) meliputi yaitu: kerja keras, orientasi masa depan, tingkat cita-cita yang tinggi, orientasi tugas / sasaran, usaha untuk maju, ketekunan, rekan kerja yang di pilih dan pemanfaatan waktu.

\section{Disiplin Kerja}

Disiplin merupakan kemampuan untuk menguasai diri dan melaksanakan norma yang berlaku dalam kehidupan bersama. Disiplin kerja dapat terlihat apabila pegawai datang ke kantor teratur dan tepat waktu, jika mereka berpakaian rapi ditempat kerja, jika mereka menggunakan perlengkapan kantor dengan baik, jika mereka menghasilkan jumlah dan kualitas pekerjaan yang memuaskan dengan mengikuti cara kerja yang telah ditentukan dan jika mereka menyelesaikan pekerjaan dengan tepat waktu.

Disiplin kerja merupakan alat yang digunakan para manajer untuk berkomunikasi dengan karyawan agar mereka bersedia untuk mengubah suatu perilaku serta sebagai suatu upaya untuk meningkatkan kesadaran dan kesediaan mentaati semua peraturan perusahaan dan norma-norma sosial yang berlaku (Rivai, 2009:825).

Menurut (M. S. . Hasibuan, 2014) kedisiplinan merupakan fungsi operatif MSDM yang terpenting karena semakin baik disiplin karyawan, semakin tinggi prestasi kerja yang dapat dicapainya. Disiplin yang baik mencerminkan besarnya rasa tanggung jawab seseorang terhadap tugas-tugas yang diberikan kepadanya. Disiplin sebagai sikap kesediaan dan kerelaan seseorang untuk mematuhi dan menaati norma-norma peraturan yang berlaku disekitarnya. Disiplin pegawai yang baik akan mempercepat tujuan organisasi bagi sebuah instansi, sedangkan disiplin yang rendah akan menjadi penghalang dan memperlambat pencapaian tujuan tersebut, (Singodimedjo dalam (Agustini, 2011). Disiplin kerja adalah kesadaran dan kesediaan seseorang menaati semua peraturan dan norma sosial yang berlaku, (Hasibuan, 2014). Disiplin kerja adalah sikap kejiawaan atau kelompok yang senantiasa berkehendak untuk mengikuti dan mematuhi segala peraturan yang ditentukan (Anoraga, 2009).

Dengan adanya tata tertib yang ditetapkan, tidak dengan sendirinya para pegawai akan mematuhinya. Perlu bagi pihak instansi mengkondisikan pegawainya dengan tata tertib yang ada dalam instansi tersebut. Terdapat faktor-faktor yang mempengaruhi disiplin, (Singodimedjo dalam Agustini, 2011) adalah sebagai berikut : 1). Ada/tidaknya pengawasan pimpinan, 2). Ada/tidaknya keteladanan pemimpin dalam organisasi, 3). Ada/tidaknya aturan pasti yang dapat dijadikan pegangan, 4). Keberanian pemimpin dan mengambil tindakan, 5). Ada/tidaknya perhatian kepada para pegawai, dan 6). Diciptakannya kebiasaan-kebiasaan yang mendukung tegaknya disiplin. Ada beberapa indikator disiplin menurut (Agustini, 2011) yaitu tingkat kehadiran, tata cara kerja, ketaatan pada atasan, kesadaran bekerja dan tanggung jawab. Apabila dalam diri pegawai telah tertanam kelima indikator tersebut, maka seorang pegawai telah mencerminkan disiplin yang baik dan bertanggungjawab terhadap tugas-tugas yang diberikan kepadanya. 


\section{Kerangka Konseptual}

Kerangka konseptual disajikan untuk melihat gambaran mengenai hubungan antara independent variabel atau variabel bebas (pengawasan, motivasi dan disiplin) terhadap dependent variabel atau variabel terikat (kinerja).

\section{Pengaruh Pengawasan Terhadap Kinerja}

Pengawasan pada hakikatnya mengatur apakah kegiatan sesuai dengan persyaratan-persyaratan yang ditentukan dalam perencanaan. Pengawaasan harus melihat kedepan walaupun hal-hal yang lalu perlu dipelajari. Itu berarti bahwa pengawasan bukanlah sekedar mengawasi tetapi harus dapat membandingkan hasil pekerjaan yang telah dilaksanakan dengan standar yang ditetapkan.

Menurut (Kadarisman, 2014), pimpinan dalam melakukan pengawasan terhadap kinerja anggota-anggota organisasinya, adalah untuk mengetahui pelaksanaan tugas atau pekerjaan yang dibebankan kepadanya, adakah kendala atau hambatan yang dihadapinya, apabila ada maka sejauh mana pengaruhnya terhadap pelaksanaan tugas guna tercapainya tujuan organisasi. Dengan demikian pengawasan terhadap pegawai memiliki peran yang sangat penting bagi suatu organisasi baik instansi maupun perusahaan swasta untuk meningkatkan kinerja pegawai yang maksimal. Hasil penelitian (Jufrizen, 2016); (Dewi, 2012); (Syahrianti, Hasmin, \& Gunawan, 2018) dan (Rompas, Tewal, \& Dotulong, 2018) yang menyimpulkan bahwa adanya pengaruh pengawasan terhadap kinerja pegawai.

\section{Pengaruh Motivasi Terhadap Kinerja}

Berhasil atau tidaknya suatu organisasi sebagian besar ditentukan oleh pemimpin dalam meningkatkan prestasi kerja para bawahannya. Motivasi seseorang melakukan suatu pekerjaan karena adanya suatu kebutuhan hidup yang harus dipenuhi. Kebutuhan ini dapat berupa kebutuhan ekonomis dan kebutuhan non ekonomi. Dengan segala kebutuhan tersebut, seseorang dituntut untuk lebih giat dan aktif dalam bekerja untuk mencapai hal ini diperlukan adanya motivasi dalam melakukan pekerjaan, oleh karena itu jika pegawai yang mempunyai motivasi kerja yang tinggi biasanya mempunyai kinerja yang tinggi pula (Agustini, 2011).

Menurut (Kadarisman, 2014) peranan Sumber Daya Manusia yaitu pegawai sebagai sumber tenaga kerja dalam suatu unit organisasi sangat dibutuhkan untuk menghasilkan produk yang berkualitas, baik berupa materi ataupun produk berupa jasa. Kinerja pegawai tersebut, saat ini menjadi pusat perhatian dalam upayanya untuk meningkatkan kinerja yang memengaruhi efisiensi dan efektivitas organisasi. Analisis yang lebih mengkosentrasikan pada kinerja, akan lebih memberikan penekanan pada faktor utama antara lain adalah motivasi kerja pegawai. Berdasarkan hasil penelitian (Jufrizen, 2018); (Jufrizen, 2017); (Jufrizen \& Pulungan, 2017); (Marjaya \& Pasaribu, 2019) dan (Andayani \& Tirtayasa, 2019) menyimpulkan bahwa motivasi berpengaruh terhadap kinerja.

\section{Pengaruh Disiplin terhadap Kinerja}

Disiplin kerja adalah kesadaran dan kesediaan seseorang untuk mentaati semua peraturan dalam suatu organisasi dan norma-norma sosial yang berlaku. Kesadaran adalah sikap seseorang yang secara sukarela mentaati semua peraturan dan sadar akan tugas dan tanggung jawabnya. Kesediaan adalah suatu sikap, tingkah laku seseorang yang sesuai dengan peraturan organisasi baik yang tertulis maupun yang tidak tertulis. Disiplin adalah suatu bentuk pelatihan yang berusaha memperbaiki dan membentuk pengetahuan, sikap, perilaku secara sukarela dan bekerja secara kooperatif dengan pegawai lainnya serta meningkatkan kinerjanya. Disiplin merupakan faktor pengikat kerja yaitu merupakan kekuatan yang dapat memaksa tenaga kerja yang telah disepakati dan telah ditentukan oleh lembaga yang berwenang. Dengan berpegang 
pada peraturan tersebut diharapkan tujuan organisasi dapat terlaksana dengan baik dan sesuai dengan rencana yang telah ditetapkan (Hasibuan, 2014).

Dengan demikian disiplin sangat diperlukan untuk menunjang kelancaran segala aktivitas organisasi agar tujuan organisasi dapat dicapai secara maksimal. Disiplin dalam instansi akan membuat kekuatan bagi pegawai dalam meningkatkan kinerjanya, disiplin kerja pegawai yang baik akan mempercepat mewujudkan tujuan dari instansi tersebut (M. S. . Hasibuan, 2014). Hasil penelitian (Jufrizen, 2016); (Prayogi \& Nursidin, 2019); (Arif, Syaifani, Siswadi, \& Jufrizen, 2019); (Ariyanti, 2016); (Faustyna \& Jumani, 2015a); (Arda, 2017a) dan (Hasibuan \& Handayani, 2017) yang menyimpulkan bahwa antara variabel disiplin mempunyai pengaruh yang signifikan terhadap kinerja.

\section{Pengaruh Pengawasan, Motivasi dan Disiplin Kerja terhadap Kinerja}

Motivasi terbentuk dari sikap pegawai dalam menghadapi situasi kerja ditempat kerja. Motivasi merupakan kondisi atau energi yang menggerakkan pegawai yang terarah untuk mencapai tujuan organisasi maupun pegawai itu sendiri. Sikap mental pegawai yang pro dan positif terhadap situasi kerja itulah yang memperkuat motivasi kerjanya untuk mencapai kinerja yang maksimal. Motivasi juga memiliki hubungan dengan kinerja sehingga untuk meningkatkan hasil kerja maka motivasi memiliki pengaruh penting terhadap kinerja pegawai karena berhasil atau tidaknya suatu organisasi dalam mencapai tujuan ditentukan juga oleh motivasi untuk menyelesaikan pekerjaan dengan lebih baik (Kadarisman, 2014).

Hasibuan (2014) mengemukakan bahwa disiplin kerja adalah kesadaran dan kesediaan seseorang menaati semua peraturan instansi dan norma-norma sosial yang berlaku, kedisiplinan merupakan suatu sikap,tingkah laku, dan perbuatan yang sesuai dengan peraturan dari instansi yang tertulis maupun tidak.

Kinerja pegawai merupakan perwujudan atau penampilan seorang pegawai dalam pelaksanaan pekerjaan.Seseorang dapat dikatakan berprestasi baik, manakala mereka dapat melaksanakan pekerjaan dengan baik artinya mencapai sasaran atau standar kerja yang telah ditetapkan sebelum atau bahkan melebihi standar yang telah ditentukan. Tingkat kedisiplinan pegawai yang semakin meningkat dalam melaksanakan pekerjaan akan berpengaruh terhadap kinerja pegawai. Berdasarkan kerangka konseptual tersebut di atas, penulis menyimpulkan dalam bentuk kerangka konsep tersebut berikut ini :

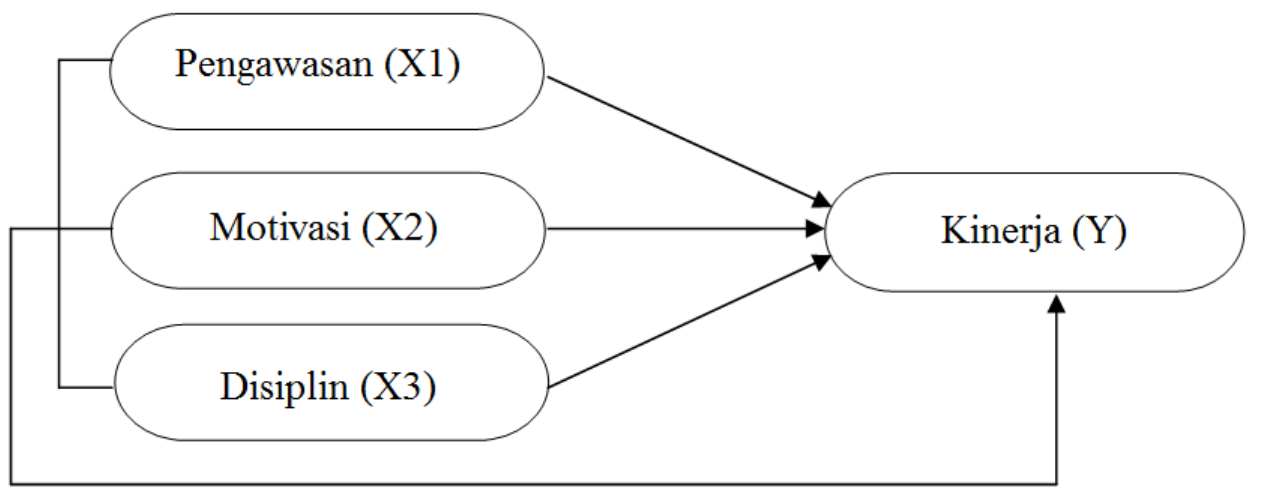

\section{METODE PENELITIAN}

Pendekatan dalam penelitian ini adalah dengan menggunakan pendekatan asosiatif, pendekatan asosiatif adalah pendekatan dimana untuk mengetahui bahwa adanya hubungan atau pengaruh diantara kedua variabel (variabel bebas dan variabel terikat). Populasi penelitian 
ini adalah seluruh guru tetap pada Yayasan Pendidikan Islam Terpadu Kuntum Bumi Rantauprapat yang berjumlah 39 orang. Pada penelitian ini, dikarenakan jumlah populasi sedikit maka sampel pada penelitian ini menggunakan keseluruhan populasi yang ada yaitu 39 orang guru menggunakan sampling jenuh. Menurut (Sugiyono, 2017) sampling jenuh yaitu teknik penetuan sampel bila semua anggota populasi digunakan sebagai sampel. Teknik pengumpulan data yang digunakan pada penelitian ini adalah menggunakan angket atau kuesioner yaitu metode pengumpulan data dengan membuat daftar pertanyaan dalam bentuk angket yang ditujukan kepada pegawai di objek penelitian yaitu Yayasan Pendidikan Islam Terpadu Kuntum Bumi Rantauprapat dengan menggunakan Skala Likert dengan bentuk checklist dimana setiap pertanyaan mempunyai 5 opsi. Teknik analisis yang digunakan dalam penelitian ini adalah analisis Regresi Linear Berganda. Analisis regresi linear digunakan untuk mengetahui pengaruh dari variabel bebas terhadap variabel terikat.

\section{HASIL DAN PEMBAHASAN \\ Hasil Penelitian}

Hasil pengolahan data dengan SPSS tentang pengaruh variabel pengawasan, motivasi dan disiplin kerja terhadap kinerja guru, maka dapat di lihat dengan menggunakan asumsi klasik yaitu :

\section{Uji Normalitas}

Uji normalitas untuk melihat apakah dalam model regresi, variabel dependen dan independennya memiliki distribusi normal atau tidak. Jika data menyebar di sekitar garis diagonal dan mengikuti arah garis diagonal maka model regresi memenuhi asumsi normalitas (Juliandi, Irfan, \& Manurung, 2014). Berdasarkan hasil olahan data menggunakan data SPSS versi 22,0 maka di ketahui uji normalitas menggunakan metode P-Plot adalah sebagai berikut:

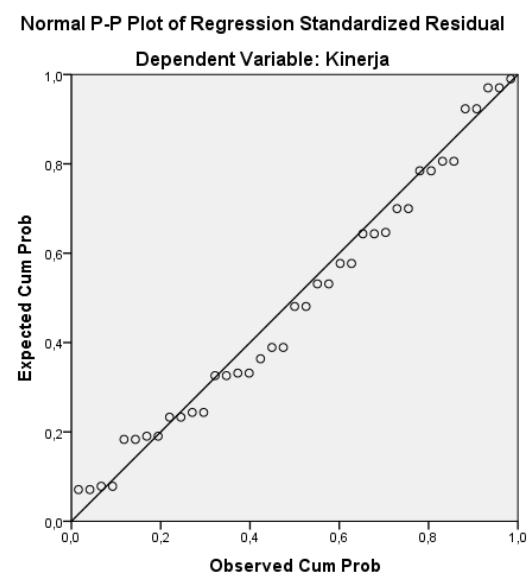

\section{Gambar 2. Uji Normalitas Menggunakan P-Plot}

Gambar tersebut menunjukkan bahwa titik-titik telah membentuk dan mengikuti arah garis diagonal pada gambar, dengan demikian dapat dinyatakan bahwa data telah terdistribusi secara normal.

\section{Uji Multikoleniaritas}

Uji Multikoleniaritas bertujuan untuk menguji apakah model regresi ditemukan adanya korelasi yang kuat antara variabel independen dengan melihat nilai VIF (variance inflasi factor) tidak melebihi 4 atau 5 (Hines dan Montgomery dalam (Juliandi, Irfan, \& Manurung, 2015). 


\begin{tabular}{|c|c|c|c|c|c|c|}
\hline \multirow[b]{2}{*}{ Mode } & & \multicolumn{3}{|c|}{ Correlations } & \multicolumn{2}{|c|}{ Collinearity Statistics } \\
\hline & & Zero-order & Partial & Part & Tolerance & VIF \\
\hline \multirow[t]{4}{*}{1} & (Constant) & & & & & \\
\hline & Pengawasan & ,364 & ,276 &, 254 & ,443 & 2,257 \\
\hline & Motivasi & ,378 &, 313 & ,292 &, 734 & 1,362 \\
\hline & Disiplin Kerja & ,279 &,- 122 &,- 109 & ,370 & 2,706 \\
\hline
\end{tabular}

a. Dependent Variable: Kinerja

Jika dilihat pada tabel 1 diketahui bahwa variabel Pengawasan $\left(\mathrm{X}_{1}\right)$, Motivasi $\left(\mathrm{X}_{2}\right)$ dan Disiplin Kerja $\left(\mathrm{X}_{3}\right)$ telah terbebas dari multikolinieritas dimana masing-masing nilai VIF yaitu $1.012<4$ atau 5 .

\section{Uji Heteroskedastisitas}

Uji heteroskedastisitas bertujuan untuk menguji apakah dalam model regresi terjadi ketidaknyamanan vaiance dari residual pengamatan satu ke pengamatan yang lain. Jika variance residual dari suatu pengamatan yang lain tetap maka dikatakan homokedastisitas, dan jika variance berbeda dikatakan heteroskedastisitas (Juliandi \& Irfan, 2014).

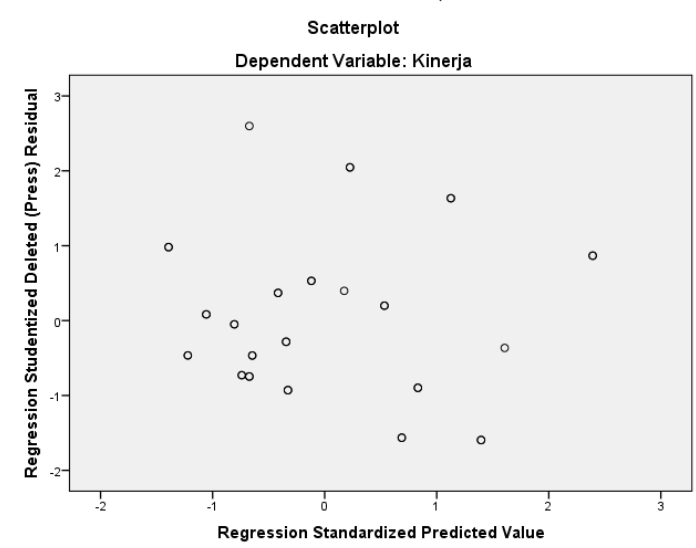

\section{Gambar 3. Uji Heteroskedastisitas}

Uji ini akan menyatakan terbebas dari Heteroskedastisitas jika titik-titik yang terdapat pada gambar tersebar secara acak. Gambar di atas menunjukkan suatu pola yang tidak jelas menyebar baik diatas maupun dibawah angka 0 pada sumbu $Y$.

\section{Regresi Linier Berganda}

Berdasarkan olahan data yang telah dilakukan, maka dapat diketahui bahwa model hubungan dari analisis regresi linier berganda dapat dilihat dari tabel berikut ini :

Tabel 2. Regresi Linier Berganda

\begin{tabular}{|c|c|c|c|c|c|c|}
\hline \multirow[b]{2}{*}{ Mod } & & \multicolumn{2}{|c|}{ Unstandardized Coefficients } & \multirow{2}{*}{$\begin{array}{c}\text { Standardized } \\
\text { Coefficients } \\
\text { Beta } \\
\end{array}$} & \multirow[b]{2}{*}{$t$} & \multirow[b]{2}{*}{ Sig. } \\
\hline & & $\mathrm{B}$ & Std. Error & & & \\
\hline \multirow[t]{4}{*}{1} & (Constant) & 11,856 & 10,332 & & 1,147 &, 259 \\
\hline & Pengawasan &, 415 & ,244 & ,382 & 1,699 & ,098 \\
\hline & Motivasi & ,466 & ,239 & ,340 & 1,951 & ,059 \\
\hline & Disiplin Kerja & , 170 & ,234 & , 179 &, 728 &, 472 \\
\hline
\end{tabular}

a. Dependent Variable: Kinerja 
Berdasarkan pada tabel 2 maka dapat disusun model penelitian persamaan regresinya adalah sebagai berikut :

$\mathrm{Y}=11,856+0,415 \mathrm{X}_{1}+0,466 \mathrm{X}_{2}+0,170 \mathrm{X}_{3}$

Model persamaan regresi berganda tersebut bermakna:

a. Nilai Konstanta sebesar 11,856 yang berarti bahwa jika variabel independen yaitu Pengawasan $\left(\mathrm{X}_{1}\right)$, Motivasi $\left(\mathrm{X}_{2}\right)$ dan Disiplin Kerja $\left(\mathrm{X}_{3}\right)$ sama dengan nol, maka kinerja (Y) adalah sebesar 11,856.

b. Nilai koefisien regresi $X_{1}=0,415$ menunjukkan apabila pengawasan mengalami kenaikan sebesar $100 \%$ maka akan meningkatkan kinerja guru Yayasan Pendidikan Islam Terpadu Kuntum Bumi Rantaurapat sebesar 41,5\% kontribusi yang diberikan pengawasan terhadap kinerja guru dilihat dari standartdied coefficients pada tabel 2 diatas.

c. Nilai koefisien regresi $\mathrm{X}_{2}=0,466$ menunjukkan apabila motivasi mengalami kenaikan sebesar 100\% maka akan mengakibatkan meningkatnya kinerja guru Yayasan Pendidikan Islam Terpadu Kuntum Bumi Rantaurapat sebesar 46,6\% kontribusi yang diberikan motivasi terhadap kinerja guru dilihat dari standartdied coefficients pada tabel 2 diatas.

d. Nilai koefisien regresi $\mathrm{X}_{3}=0,170$ menunjukkan apabila disiplin kerja mengalami kenaikan sebesar $100 \%$ maka akan mengakibatkan meningkatnya kinerja guru Yayasan Pendidikan Islam Terpadu Kuntum Bumi Rantaurapat sebesar 17\% kontribusi yang diberikan disiplin kerja terhadap kinerja guru dilihat dari standartdied coefficients pada tabel 2 diatas.

\section{Uji Hipotesis}

\section{Uji Parsial ( Uji t )}

Uji statistik t dilakukan untuk menguji apakah variabel bebas (X) secara individual mempunyai pengaruh yang signifikan atau tidak terhadap variabel terikat (Y).

\section{Tabel 3. Uji t}

\begin{tabular}{|c|c|c|c|c|c|c|}
\hline \multirow[b]{2}{*}{ Mode } & & \multicolumn{2}{|c|}{ Unstandardized Coefficients } & \multirow{2}{*}{$\begin{array}{c}\begin{array}{c}\text { Standardized } \\
\text { Coefficients }\end{array} \\
\text { Beta }\end{array}$} & \multirow[b]{2}{*}{$t$} & \multirow[b]{2}{*}{ Sig. } \\
\hline & & $\mathrm{B}$ & Std. Error & & & \\
\hline \multirow[t]{4}{*}{1} & (Constant) & 11,856 & 10,332 & & 1,147 &, 259 \\
\hline & Pengawasan & ,415 & ,244 & ,382 & 1,699 &, 098 \\
\hline & Motivasi & ,466 & ,239 &, 340 & 1,951 &, 059 \\
\hline & Disiplin Kerja & .170 & .234 & 179 & .728 & .472 \\
\hline
\end{tabular}

a. Dependent Variable: Kinerja

\section{Pengaruh Pengawasan Terhadap Kinerja}

Pada tabel di atas dapat di ketahui bahwa variabel $\mathrm{X}_{1}$ yaitu pengawasan memiliki signifikansi sebesar 0,098 lebih besar dari 0,05, artinya bahwa pengawasan berpengaruh tidak signifikan terhadap kinerja guru Yayasan Pendidikan Islam Terpadu Kuntum Bumi Rantauprapat. Dari tabel 3 tentang pengaruh pengawasan $\left(\mathrm{X}_{1}\right)$ terhadap kinerja $(\mathrm{Y})$ diperoleh nilai $t_{\text {hitung }} 1.699<\mathrm{t}_{\text {tabel }} 2.026$ dengan probabilitas Sig 0,098, lebih besar dari $\alpha=0,05$. Dapat di simpulkan bahwa pengawasan $\left(\mathrm{X}_{1}\right)$ secara parsial mempunyai pengaruh tidak signifikan terhadap kinerja (Y) pada Yayasan Pendidikan Islam Terpadu Kuntum Bumi Rantauprapat.

\section{Pengaruh Motivasi Terhadap Kinerja}

Pada tabel 3 di atas dapat diketahui bahwa variabel $\mathrm{X}_{2}$ yaitu motivasi memiliki signifikan sebesar 0,059 lebih besar dari 0,05, artinya bahwa motivasi berpengaruh tidak signifikan terhadap kinerja guru pada Yayasan Pendidikan Islam Terpadu Kuntum Bumi Rantauprapat. 
Dari tabel 3 tentang pengaruh motivasi $\left(\mathrm{X}_{2}\right)$ terhadap kinerja $(\mathrm{Y})$ diperoleh nilai $\mathrm{t}_{\text {hitung }} 1,951<$ $\mathrm{t}_{\text {tabel }} 2.026$ dengan probabilitas Sig 0,059, lebih besar dari $\alpha=0,05$. Dapat di simpulkan bahwa motivasi $\left(\mathrm{X}_{2}\right)$ secara parsial mempunyai pengaruh tidak signifikan terhadap kinerja $(\mathrm{Y})$ pada Yayasan Pendidikan Islam Terpadu Kuntum Bumi Rantauprapat.

\section{Pengaruh Disiplin Kerja Terhadap Kinerja}

Pada tabel 3 di atas dapat diketahui bahwa variabel $\mathrm{X}_{3}$ yaitu disiplin kerja memiliki signifikan sebesar 0,472 lebih besar dari 0,05, artinya bahwa disiplin kerja berpengaruh tidak signifikan terhadap kinerja guru Yayasan Pendidikan Islam Terpadu Kuntum Bumi Rantauprapat. Dari tabel 3 tentang pengaruh disiplin kerja $\left(\mathrm{X}_{3}\right)$ terhadap kinerja $(\mathrm{Y})$ diperoleh nilai $t_{\text {hitung }} 0,728<\mathrm{t}_{\text {tabel }} 2,026$ dengan probabilitas Sig 0,472, lebih besar dari $\alpha=0,05$. Dapat di simpulkan bahwa Disiplin Kerja $\left(\mathrm{X}_{3}\right)$ secara parsial mempunyai pengaruh tidak signifikan terhadap Kinerja (Y) pada Yayasan Pendidikan Islam Terpadu Kuntum Bumi Rantauprapat.

\section{Uji Simultan ( Uji F )}

Uji statistik F (simultan) dilakukan untuk mengetahui apakah variabel bebas (independent) secara bersama-sama berpengaruh secara signifikan atau tidak terhadap variabel terikat (dependen). Hasil uji secara simultan dapat dilihat dari tabel dibawah ini :

\section{Tabel 4. Uji F}

\begin{tabular}{|ll|r|r|r|r|r|}
\hline \multicolumn{1}{|c|}{ MNOVA $^{\text {a }}$} \\
\hline 1 & Sum of Squares & \multicolumn{1}{c|}{ Df } & Mean Square & F & \multicolumn{1}{c|}{ Sig. } \\
\hline & Regression & 103,448 & 3 & 34,483 & 3,242 &, $034^{\mathrm{b}}$ \\
& Residual & 372,295 & 35 & 10,637 & & \\
Total & 475,744 & 38 & & & \\
\hline
\end{tabular}

a. Dependent Variable: Kinerja

b. Predictors: (Constant), Disiplin Kerja, Motivasi, Pengawasan

Berdasarkan dari tabel uji $\mathrm{F}$ diketahui bahwa terdapat nilai signifikan sebesar 0,034 nilai signifikan ini lebih kecil dari 0,05 artinya bahwa Pengawasan, Motivasi dan Disiplin Kerja berpengaruh signifikan terhadap Kinerja Guru pada Yayasan Pendidikan Islam Terpadu Kuntum Bumi Rantauprapat.

Jika dibandingkan nilai $F_{\text {hitung }}$ dengan $F_{\text {tabel }}$ maka dihasilkan 3,242 >2,869 sehingga di simpulkan bahwa Pengawasan, Motivasi dan Disiplin Kerja berpengaruh signifikaan terhadap Kinerja Guru pada Yayasan Pendidikan Islam Terpadu Kuntum Bumi Rantauprapat.

\section{Koefisien Determinasi}

Uji determinasi ini untuk melihat seberapa besar Pengawasan, Motivasi dan Disiplin Kerja dalam menjelaskan variasi variabel dependen yaitu Kinerja. Untuk mengetahui besarnya determinasi Pengawasan, Motivasi dan Disiplin Kerja dalam menjelaskan variasi variabel dependennya yaitu Kinerja dapat dilihat pada tabel berikut ini :

\section{Tabel 5. Koefisien Determinasi (R-Square)}

\begin{tabular}{|l|r|r|r|r|}
\hline Model & $\mathrm{R}$ & $\mathrm{R}$ Square & \multicolumn{1}{|c|}{$\begin{array}{c}\text { Adjusted } \mathrm{R} \\
\text { Square }\end{array}$} & $\begin{array}{c}\text { Std. Error of the } \\
\text { Estimate }\end{array}$ \\
\hline 1 &, $466^{\mathrm{a}}$ &, 217 &, 150 & 3,26144 \\
\hline
\end{tabular}

a. Predictors: (Constant), Disiplin Kerja, Motivasi, Pengawasan

b. Dependent Variable: Kinerja

Berdasarkan pada tabel di atas diketahui bahwa nilai $\mathbf{R}_{\text {square }}$ adalah sebesar 0,217 atau sama dengan 21,70\% artinya bahwa Pengawasan, Motivasi dan Disiplin Kerja mampu untuk 
menjelaskan Kinerja di Yayasan Pendidikan Islam Terpadu Kuntum Bumi Rantauprapat adalah sebesar $21,70 \%$ dan sisanya $78,30 \%$ dijelaskan oleh variabel bebas yang lainnya yang tidak diikutsertakan ke dalam model penelitian ini.

\section{Pembahasan}

\section{Pengaruh Pengawasan terhadap Kinerja}

Berdasarkan hasil penelitian mengenai pengaruh antara pengawasan terhadap kinerja pada Yayasan Pendidikan Islam Terpadu Kuntum Bumi Rantauprapat yang menyatakan $t_{\text {hitung }} \leq$ $t_{\text {tabel }}$ yaitu $1.699 \leq 2.026$ berada di daerah penerimaan $\mathrm{H} 0$ sehingga Ha ditolak, hal ini dinyatakan bahwa pengawasan berpengaruh tidak signifikan secara parsial terhadap kinerja guru di Yayasan Pendidikan Islam Terpadu Kuntum Bumi Rantauprapat. Artinya tingkat pengawasan secara positif maupun negatif dapat mempengaruhi kinerja guru pada yayasan tersebut. Hasil penelitian ini menyatakan bahwa ada pengaruh antara pengawasan terhadap kinerja. Hal ini sejalan dengan hasil penelitian terdahulu (Abyad, 2013); (Irawan, Widiana, \& Iman, 2017); (Jufrizen, 2016); dan (Lukas, Tewal, \& Walangitan, 2017) yang menunjukkan bahwa pengawasan berpengaruh terhadap kinerja.

\section{Pengaruh Motivasi terhadap Kinerja}

Berdasarkan hasil penelitian mengenai pengaruh antara motivasi terhadap kinerja guru pada Yayasan Pendidikan Islam Terpadu Kuntum Bumi Rantauprapat yang menyatakan $t_{\text {hitung }} \leq$ $t_{\text {tabel }}$ yaitu $1.951 \leq 2.026$ berada di daerah penerimaan $\mathrm{H} 0$ sehingga Ha ditolak, hal ini di nyatakan bahwa motivasi berpengaruh tidak signifikan secara parsial terhadap kinerja guru di Yayasan Pendidikan Islam Terpadu Kuntum Bumi Rantauprapat. Hasil penelitian ini menyatakan bahwa ada pengaruh antara motivasi terhadap kinerja. Hal ini sejalan dengan hasil penelitian terdahulu (J. Jufrizen, 2018); (Ainanur \& Tirtayasa, 2018); (Rosmaini \& Tanjung, 2019); (Astuti \& Suhendri, 2019); (Jufrizen, 2017); (J. S. Hasibuan \& Handayani, 2017); (Farisi, Irnawati, \& Fahmi, 2020); (Gultom, 2014); (Astuti \& Lesmana, 2018) dan (Bukhari \& Pasaribu, 2019) yang menunjukkan bahwa motivasi berpengaruh terhadap kinerja.

\section{Pengaruh Disiplin Kerja terhadap Kinerja}

Berdasarkan hasil penelitian mengenai pengaruh antara Disiplin Kerja terhadap Kinerja pada Yayasan Pendidikan Islam Terpadu Kuntum Bumi Rantauprapat yang menyatakan $t_{\text {hitung }} \leq$ $\mathrm{t}_{\text {tabel }}$ yaitu $0.728 \leq 2.026$ berada di daerah penerimaan $\mathrm{H} 0$ sehingga Ha ditolak, hal ini di nyatakan bahwa Disiplin Kerja berpengaruh tidak signifikan secara parsial terhadap Kinerja guru di Yayasan Pendidikan Islam Terpadu Kuntum Bumi Rantauprapat.

Hasil penelitian ini menyatakan bahwa ada pengaruh antara disiplin kerja terhadap kinerja. Hal ini sejalan dengan hasil penelitian terdahulu (Prayogi, Lesmana, \& Siregar, 2019); (Farisi \& Fani, 2019); (Fahmi \& Sanika, 2019); (Arif et al., 2019); (Yusnandar, Nefri, \& Siregar, 2020); (Tanjung, 2015); (Arif, Maulana, \& Lesmana, 2020); (Pulungan, 2017); (Farisi et al., 2020); (Jufrizen Jufrizen, 2016); (Arda, 2017); (J. S. Hasibuan \& Handayani, 2017); (Faustyna \& Jumani, 2015) yang menunjukkan bahwa disiplin kerja berpengaruh terhadap kinerja.

\section{Pengaruh Pengawasan, Motivasidan Disiplin Kerja terhadap Kinerja}

Mengenai pengaruh antara Pengawasan, Motivasi dan Disiplin Kerja terhadap Kinerja guru di Yayasan Pendidikan Islam Terpadu Kuntum Bumi Rantauprapat pada penelitian ini sudah jelas terbukti ada pengaruh secara simultan, di mana hasil uji $\mathrm{F}$ di dapat nilai $\mathrm{F}_{\text {hitung }} \geq$ $F_{\text {tabel }}$ yaitu $3.242 \geq 2.869$ dengan signifikan $0,034<0,05$. Karena $F_{\text {hitung }}$ lebih besar dari $F_{\text {tabel }}$ 
maka H0 di tolak dan Ha di terima artinya ada pengaruh antara Pengawasan, Motivasi dan Disiplin Kerja terhadap Kinerja guru di Yayasan Pendidikan Islam Terpadu Kuntum Bumi Rantauprapat.

\section{PENUTUP}

Berdasarkan hasil penelitian dan pembahasan yang di lakukan oleh peneliti mengenai pengaruh Pengawasan, Motivasi dan Disiplin Kerja terhadap Kinerja guru di Yayasan Pendidikan Islam Terpadu Kuntum Bumi Rantauprapat, maka dapat di tarik kesimpulan bahwa secara parsial pengawasan, motivasi dan disiplin kerja dan berpengaruh positif tidak signifikan terhadap kinerja guru pada Yayasan Pendidikan Islam Terpadu Kuntum Bumi Rantauprapat. Dan secara simultan pengawasan, motivasi dan disiplin kerja secara simultan berpengaruh positif signifikan terhadap kinerja guru pada Yayasan Pendidikan Islam Terpadu Kuntum Bumi Rantauprapat. Berdasarkan kesimpulan diatas, maka dalam hal ini penulis dapat menyarankan hal-hal sebagai berikut : 1). Seorang guru akan mengerahkan segenap kemampuannya untuk melaksanakan pekerjaan bilamana dalam mengerjakan pekerjaan tersebut terdapat sistem pengawasan yang terkoordinir dan aturan yang jelas,sehingga pengawasan akan mendorong seseorang guru melakukan suatu kegiatan dengan menggunakan seluruh kemampuannya untuk mencapai tujuan. 2). Mengingat motivasi mempunyai pengaruh terhadap kinerja pegawai, maka hendaknya motivasi kerja benar-benar diperhatikan, dengan demikian diharapkan akan menciptakan suasana kerja yang kompetitif sehingga mampu meningkatkan kinerja yang tinggi. 3) Sebaiknya disiplin kerja lebih ditingkatkan lagi agar kinerja dapat meningkat sehingga instansi dapat mencapai tujuan yang maksimal sesuai dengan harapan, apabila ada pegawai yang melanggar disiplin sebaiknya di berikan hukuman yang sesuai dengan peraturan yang dilanggar. 4). Kiranya hasil penelitian ini dapat dijadikan suatu referensi sederhana dalam pertimbangan kebijakan yang ada, sehingga pembaharuan pola untuk meningkatkan kinerja dan menjaga suatu keharmonisan antara guru dan organisasi dapat berjalan dengan baik.

\section{DAFTAR PUSTAKA}

Abyad, S. N. (2013). Pengaruh Pengawasan terhadap Kinerja Pegawai pada Kantor BAPPEDA Kabupaten Kutai Kartanegara. PREDIKSI, 2(1), 18-29. https://doi.org/10.31293/pd.v2i1.431

Agustini, F. (2011). Manajemen Sumber Daya Manusia Lanjutan. Medan: Madenatera.

Ainanur, A., \& Tirtayasa, S. (2018). Pengaruh Budaya Organisasi, Kompetensi dan Motivasi Terhadap Kinerja Karyawan. Maneggio: Jurnal Ilmiah Magister Manajemen, 1(1), 1-14. https://doi.org/10.30596/maneggio.v1i1.2234

Andayani, I., \& Tirtayasa, S. (2019). Pengaruh Kepemimpinan, Budaya Organisasi, Dan Motivasi Terhadap Kinerja Pegawai. Maneggio: Jurnal Ilmiah Magister Manajemen, 2(1), 45-54. https://doi.org/10.30596/maneggio.v2i1.3367

Anoraga, P. (2009). Manajemen Bisnis. Jakarta: PT Rineka Cipta.

Arda, M. (2017). Pengaruh Kepuasan Kerja Dan Disiplin Kerja Terhadap Kinerja Karyawan Pada Bank Rakyat Indonesia Cabang Putri Hijau Medan. Jurnal Ilmiah Manajemen Dan Bisnis, 18(1), 45-60. https://doi.org/10.30596/jimb.v18i1.1097

Arianty, N., Bahagia, R., Lubis, A. A., \& Siswadi, Y. (2016). Manajemen Sumber Daya Manusia. Medan: Perdana Publishing.

Arif, M., Maulana, T., \& Lesmana, M. T. (2020). Pengaruh Disiplin Kerja dan Kemampuan Kerja Terhadap Prestasi Kerja Karyawan. Jurnal Humaniora: Jurnal Ilmu Sosial, Ekonomi Dan Hukum, 4(1), 106-119. https://doi.org/10.30601/humaniora.v4i1.515

Arif, M., Syaifani, P. E., Siswadi, Y., \& Jufrizen, J. (2019). Effect of Compensation and 
Discipline on Employee Performance. In Proceeding of The 3rd International Conference on Accounting, Business \& Economics (UII-ICABE 2019) (pp. 263-276).

Arianty, N. (2016). Pengaruh Kepemimpinan dan Disiplin Kerja Tehadap Kinerja Karyawan Pada PT Pelindo Cabang Belawan. Jurnal Manajemen Perpajakan, 4 (2), 400-410.

Astuti, R., \& Lesmana, O. P. A. (2018). Pengaruh Motivasi dan Beban Kerja Terhadap Kinerja Perawat Pada Rumah Sakit Umum Mitra Medika Medan. Jurnal Ilmu Manajemen, 6(2), 42-50.

Astuti, R., \& Suhendri, S. (2019). Pengaruh Kompensasi Dan Motivasi Terhadap Kinerja Karyawan pada PT. Tunas Jaya Utama. Jurnal Manajemen Bisnis Eka Prasetya: Penelitian Ilmu Manajemen, 5(2), 1-10.

Bukhari, B., \& Pasaribu, S. E. (2019). Pengaruh Motivasi, Kompetensi, Dan Lingkungan Kerja Terhadap Kinerja. Maneggio : Jurnal Ilmiah Magister Manajemen, 2(1), 89-103.

Daulay, R., Pasaribu, H. K., Putri, L. P., \& Astuti, R. (2017). Manajeman. Medan: Lembaga Penelitian Dan Penulisan AQLI.

Dewi, S. P. (2012). Pengaruh Disiplin dan Pengawasan Kerja Terhadap Kinerja Karyawan Pada PT. Karyadeka Alam Lestari Semarang. Jurnal Nominal, I Nomor I. https://doi.org/10.1080/13574809.2016.1234336

Fahmi, M., \& Sanika, F. (2019). The Influence of Leadership and Work Discipline Towards Employee Performance at PT. Kereta Api Indonesia (Persero) Divisi Regional I Sumatera Utara. In Proceedings of the 5th International Conference of Project Management (ICPM) Yogyakarta 2019 (pp. 161-167).

Farisi, S., \& Fani, W. M. (2019). Influence Of Work Environment And Work Discipline On Employee Perfomance. International Conference on Global Education VII, 69-81.

Farisi, S., Irnawati, J., \& Fahmi, M. (2020). Pengaruh Motivasi dan Disiplin Kerja Terhadap Kinerja Karyawan. Jurnal Humaniora: Jurnal Ilmu Sosial, Ekonomi Dan Hukum, 4(1), 15-33. https://doi.org/10.30601/humaniora.v4i1.420

Faustyna, F., \& Jumani, J. (2015). Pengaruh Pengembangan Karir Dan Disiplin Kerja Terhadap Kinerja Karyawan Pada PT.Pelabuhan Indonesia I (PERSERO) Medan. Jurnal Ilmiah Manajemen Dan Bisnis, 15(01), 71-79.

Gultom, D. K. (2014). Pengaruh Budaya Organisasi Perusahaan Dan Motivasi Terhadap Kinerja Karyawan pada PT. Perusahaan Gas Negara (Persero) Tbk Medan. Jurnal Ilmiah Manajemen Dan Bisnis, 14(2), 176-184. https://doi.org/10.30596/jimb.v14i2.194

Handoko, T. H. (2010). Manajemen (2nd ed.). Yogyakarta: BPFE-Yogyakarta.

Hasibuan, J. S., \& Handayani, R. (2017). Pengaruh Disiplin dan Motivasi Terhadap Kinerja Karyawan Pada PT. Kemasindo Cepat Nusantara Medan. Kumpulan Jurnal Dosen Universitas Muhammadiyah Sumatera Utara, 418-428.

Hasibuan, M. S. . (2014). Manajemen Sumber Daya Manusia. Jakarta: Bumi Aksara.

Irawan, D. N., Widiana, M. E., \& Iman, N. (2017). Pengaruh Pengawasan, Keterlibatan Kerja Dan Gaya Kepemimpinan Terhadap Kinerja Karyawan Di PT. Assa Land Marvell City Surabaya. Jurnal Manajemen Branchmark, 3(3), 877-891.

Jufrizen, J. (2018). Peran Motivasi Kerja Dalam Memoderasi Pengaruh Kompensasi Dan Disiplin Kerja Terhadap Kinerja Karyawan. Prosiding: The National Conferences Management and Business (NCMAB) 2018, 405-424.

Jufrizen, J. (2016). Pengaruh Pengawasan Terhadap Kinerja Karyawan Melalui Disiplin Kerja Pada PT. Socfin Indonesia Medan. Jurnal Ilmiah Manajemen Dan Bisnis, 17(2), 181-195.

Jufrizen, J. (2017). Pengaruh kemampuan dan motivasi terhadap kinerja perawat Studi pada Rumah Sakit Umum Madani Medan. Jurnal Riset Sains Manajemen, 1(1), 27-34. https://doi.org/10.5281/zenodo.1036809 
Jufrizen, J, \& Pulungan, D. R. (2017). Implementation of Incentive and Career Development of Performance with Motivation as an Intervening Variable. In Proceedings of AICS-Social Sciences (pp. 441-446).

Juliandi, A., \& Irfan, I. (2014). Metodologi Penelitian Kuantitatif. Bandung: Citapustaka Media Perintis.

Juliandi, A., Irfan, I., \& Manurung, S. (2014). Metodologi Penelitian Bisnis, Konsep dan Aplikasi: Sukses Menulis Skripsi \& Tesis Mandiri. Medan: UMSU Press.

Juliandi, A., Irfan, I., \& Manurung, S. (2015). Metode Penelitian Bisnis : Konsep \& Aplikasi. In F. Zulkarnain (Ed.). Medan : UMSU PRESS.

Kadarisman, M. (2014). Manajemen Pengembangan Sumber Manusia. Jakarta: Rajawali Pers. Kasmir, K. (2016). Manajemen Sumber Daya Manusia. Jakarta: PT Rajagrafindo Persada.

Lukas, M., Tewal, B., \& Walangitan, M. D. (2017). Pengaruh Pengawasan, Kepemimpinan Dan Kompensasi Terhadap Kinerja Pegawai Pada Badan Pengelola Keuangan Dan Barang Milik Daerah Kabupaten Minahasa Utara. Jurnal EMBA: Jurnal Riset Ekonomi, Manajemen, Bisnis Dan Akuntansi, 5(2), 1921-1928. https://doi.org/10.35794/emba.v5i2.16465

Mangkunegara, A. A. A. P. (2018). Manajemen Sumber Daya Manusia Perusahaan. (S. Sandiasih, Ed.). Bandung: PT. Remaja Rosdakarya Offset.

Marjaya, I., \& Pasaribu, F. (2019). Pengaruh Kepemimpinan, Motivasi, Dan Pelatihan Terhadap Kinerja Pegawai. Maneggio: Jurnal Ilmiah Magister Manajemen, 2(1), 129147. https://doi.org/10.30596/maneggio.v2i1.3650

Prayogi, M. A., Lesmana, M. T., \& Siregar, L. H. (2019). The Influence of Communication and Work Discipline to Employee Performance. In Proceedings of the First International Conference on Administration Science (ICAS 2019) (pp. 423-426). https://doi.org/10.2991/icas-19.2019.88

Prayogi, M. A., \& Nursidin, M. (2019). Pengaruh kompetensi dan Disiplin Kerja Terhadap Kinerja Karyawan. Festifal Riset Ilmiah Manajemen Dan Akuntansi, 1(11), 1-5.

Pulungan, D. R. (2017). Pengaruh Gaya Kepemimpinan Situasional dan Disiplin Kerja Terhadap Kinerja Pegawai Pada PT. Bakrie Telecom, Tbk Medan. Jurnal Ilmiah Kohesi, $1(1), 148-158$.

Rivai, V. (2009). Manajemen Sumber Daya Manusia Untuk Perusahaan Dari Teori Ke Praktik (Kedua). Jakarta: PT Rajagrafindo Persada.

Rompas, G. A. C., Tewal, B., \& Dotulong, L. (2018). Pengaruh Gaya Kepemimpinan, Pengawasan, Dan Disiplin Kerja Terhadap Kinerja Pegawai Pada Dinas perhubungan Kabupaten Minahasa Tenggara. Jurnal EMBA: Jurnal Riset Ekonomi, Manajemen, Bisnis Dan Akuntansi, 6(4), 1978-1987. https://doi.org/10.35794/emba.v6i4.20919

Rosmaini, R., \& Tanjung, H. (2019). Pengaruh Kompetensi, Motivasi Dan Kepuasan Kerja Terhadap Kinerja Pegawai. Maneggio: Jurnal Ilmiah Magister Manajemen, 2(1), 1-15. https://doi.org/10.30596/maneggio.v2i1.3366

Siagian, S. P. (2014). Manajemen Sumber Daya Manusia. Jakarta: Bumi Aksara.

Sugiyono, S. (2017). Metodologi Penelitian (Kuantitatif,Kualitatif,dan R\&D). Bandung: Alfabeta.

Sunyoto, D. (2012). Manajemen Sumber Daya Manusia. Jakarta: PT Buku Seru.

Sutrisno, E. (2016). Manajemen Sumber Daya Manusia. Jakarta: Kencana Prenada Media Group.

Syahrianti, N., Hasmin, H., \& Gunawan, G. (2018). Pengaruh Fasilitas Kerja, Pengawasan dan Motivasi Kerja terhadap Kinerja Pegawai pada Kantor KPU Provinsi Sulawesi Selatan. Journal of Management, 1(1), 1-16. 
Tanjung, H. (2015). Pengaruh Disiplin Kerja Dan Motivasi Kerja Terhadap Prestasi Kerja Pegawai Pada Dinas Sosial Dan Tenaga Kerja Kota Medan. Jurnal Ilmiah Manajemen Dan Bisnis, 15(1), 27-34.

Umam, K. (2012). Perilaku Organisasi. Bandung: Pustaka Setia.

Wibowo, W. (2014). Perilaku Dalam Organisasi. Jakarta: Rajawali Pres.

Winardi, W. (2012). Manajemen Sumber Daya Manusia. Jakarta: Prenada Media Group.

Yusnandar, W., Nefri, R., \& Siregar, S. (2020). Pengaruh Disiplin Kerja Dan Pelatihan Terhadap Kinerja Karyawan Dengan Budaya Organisasi Sebagai Variabel Moderasi Pada Rumah Sakit Milik Pemerintah di Kota Medan. Jurnal Humaniora : Jurnal Ilmu Sosial, Ekonomi Dan Hukum, 4(1), 61-72. https://doi.org/10.30601/humaniora.v4i1.433 